\title{
OCULAR HYPERTENSION ASSOCIATED WITH SIMPLE GOITRE OBSERVED IN YOUNG INDIVIDUALS*
}

\author{
BY \\ SƯREYYA GÖRDÜREN \\ From the Ophthalmology Clinic, University of Ankara, Turkey
}

\begin{abstract}
AMONG the various theories on the pathogenesis of chronic simple glaucoma, is the suggestion that cerebral disturbances of obscure origin, especially in the diencephalon, play an important part in the occurrence of glaucoma. Magitot (1950), especially, accepts that the primary cause of the factors resulting in glaucoma lies in the upper centres, and that a disturbance in the regulation of these centres influences the eye and glaucoma occurs.

Redslob (1955) has shown that degeneration of the optic nerve is more marked in the upper parts of the chiasma, and Radovici (1955) has emphasized important clues suggesting that the aetiology of glaucoma should be sought in the hypothalamus, tuber cinereum, infundibulum, and hypophyseal regions.

The mid-brain, and especially the thalamic and subthalamic centres, is important in regulating the endocrine balance of the human organism. Therefore, some relationship between chronic glaucoma and the endocrine system may well be encountered.

Five female patients and one male recently observed in the out-patients department of the Clinic of Ophthalmology, University of Ankara, have induced me to investigate this subject, because they presented features which fitted in with this possibility.

The youngest patient was 13 years old and the oldest was 41 ; a hypertrophic thyroid gland was noted in all of them at the first inspection. All the young females had a hyperemotive status and labile nervous system, and complained of head and orbital pains of varying severity and also of irregular hypo- or dys-menorrhoea. The male patient was the brother of one of the females. In all the patients the ocular tension was found to be above normal.
\end{abstract}

\section{Case Reports}

Case 1, a married woman aged 36, was first seen on November 7, 1957, complaining of blurring of vision and headaches.

Examination.-The anterior segments and fundi of both eyes were normal, the visual acuity 5/6, and the ocular tension $30 \mathrm{~mm}$. $\mathrm{Hg}$ (Schiötz). Perimetric and campimetric

* Received for publication July 24, 1961. 
examination showed no abnormality. Gonioscopy showed open angles. The curve obtained by the Goldmann-Weekers adaptometer showed a rise of threshold on dark adaptation. Provocative tests were negative.

Systemic examination showed hypertrophy of the medial lobe of the thyroid, positive dermographism, and general neuro-regulatory asthenia.

Protein-bound serum iodine was above normal $(7 \cdot 9 \mu \mathrm{g}$. per cent.). The basal metabolic rate was normal. The patient was obese and complained of dysmenorrhoea.

Treatment.-She was given gutt. pilocarpine for one month and the tension was normal during this time. The pilocarpine was then stopped and $0.10 \mathrm{mg}$. Serpasil was given orally three times daily for another month. The tension was still normal and the patient's subjective complaints diminished. After the Serpasil, oestrogen and Proluton intramuscular injections were given for 15 days. No change occurred in this period. After the cessation of medical therapy, the tension remained normal in both eyes.

Case 2, an unmarried girl aged 19 years, was first seen on March 3, 1959, complaining of headaches and a feeling of heaviness in both eyes.

Examination.-She was obese with a hypertrophic thyroid gland. The anterior segments and fundi of both eyes were normal, the visual acuity was $6 / 6$ with correction for slight myopia, and the ocular tension was $28 \mathrm{~mm}$. Hg (Schiötz). Perimetric and campimetric studies showed no abnormality. Gonioscopy revealed bilateral anterior trabecular synechiae and persistent mesodermal tissues in the angles. A rise in threshold on dark adaptation was evident. The homatropine test was negative, but after the water-drinking test the initial tension of $16 \mathrm{~mm}$. $\mathrm{Hg}$ rose to $30 \mathrm{~mm}$. $\mathbf{H g}$ (Schiötz) in both eyes.

Systemic examination revealed a hypertrophic thyroid, but the basal metabolic rate and protein-bound serum iodine were normal. The patient also complained of hypomenorrhoea.

Treatment.-The tension was controlled for 9 months with pilocarpine drops, varying from 18 to $40 \mathrm{~mm}$. Hg (Schiötz). The tension was kept under control by courses of pilocarpine for 1 month, Serpasil for one month, and hormone preparations for 2 weeks.

Result.-There was no change in the irregular tension, except a relative amelioration during the administration of Serpasil.

Case 3, a boy aged 13 years, brother of Case 2, attended the out-patients department with slight hyperopia on March 25, 1959.

Examination.-The anterior segments and fundi were normal; the visual acuity was $6 / 6$ with glasses; the ocular tension was $27 \mathrm{~mm}$. $\mathrm{Hg}$ (Schiötz). Although the perimetric and campimetric investigations showed no abnormality, gonioscopy showed wide anterior chamber angles. There was a rise in the threshold for dark adaptation. The homatropine test was negative, but at the end of the water-drinking test the initial tension of $14 \mathrm{~mm}$. $\mathrm{Hg}$ in each eye rose to 38 in the right and 40 in the left. Systemic examination revealed nothing pathological except a slight hypertrophy of the thyroid. The basal metabolic rate and protein-bound serum iodine were within normal limits.

Treatment and Results.-The patient did not respond to pilocarpine, but during treatment with Serpasil and hormones (Testoviron tablets $0.5 \mathrm{mg}$. daily) he felt more comfortable.

Case 4, an unmarried woman aged 35, was first seen on May 18, 1959, complaining of a feeling of heaviness in her eyes and impairment of vision. 
Examination.-The anterior segments and fundi were normal, the visual acuity being 6/6. The ocular tension was $35 \mathrm{~mm}$. $\mathrm{Hg}$ (Schiötz) in the right eye and 25 in the left. Perimetric and campimetric tests showed no abnormality. Both angles were normal gonioscopically. A doubtful dark-adaptation curve was obtained. Systemic examination showed a simple goitre and positive dermographism; the basal metabolic rate and protein-bound serum iodine were slightly raised (8.9 $\mu \mathrm{g}$. per cent.).

The patient also had dysmenorrhoea, and thyroid enlargement.

Treatment and Results.-Pilocarpine, Serpasil, and hormone therapy were equally effective and provocative tests gave negative results.

Case 5, an unmarried woman aged 27, came to the out-patients department on September 21,1959 , complaining of palpitation, perspiration, headaches, and blurring of vision from time to time.

Examination.-The anterior segments and fundi were normal and the ocular tension $30 \mathrm{~mm}$. Hg (Schiötz). Perimetric and campimetric investigation showed no abnormality. The gonioscopic findings were normal. A considerable rise in threshold on dark adaptation was found. The homatropine test induced a rise in tension to over $40 \mathrm{~mm}$. in both eyes and blurring of vision. The latter was treated and recovered in 2 days. This strongly suggested a diagnosis of glaucoma.

Systemic examination revealed a simple goitre of nodular type, the basal metabolic rate and protein-bound serum iodine giving high percentages $(9 \mu \mathrm{g}$. per cent.). Tremor of the hands and palpitation were marked. The patient was hyperemotive and also complained of dysmenorrhoea.

Treatment.- She was helped a little by Serpasil, but did not respond to pilocarpine or hormone treatment. She was admitted to the internal diseases clinic and was given oral Propycil.

Result.-During and after this treatment the ocular tension decreased to $19 \mathrm{~mm} . \mathrm{Hg}$ (Schiötz), a reduction which had not been obtained by previous treatment. A decrease in basal metabolic rate was also observed, and the palpitations and tremor diminished. This improvement is still being maintained.

Case 6, a married woman aged 41, had attended the out-patients department on January 25,1960 , complaining of blurred vision and orbital pain.

Examination.-The anterior segments and fundi were normal, the visual acuity being 6/6. The ocular tension was $26 \mathrm{~mm}$. $\mathrm{Hg}$ (Schiötz). Perimetric and campimetric findings showed no abnormality. Gonioscopy gave normal results. A rise in the dark-adaptation threshold was evident. Provocative tests were negative. Systemic examination revealed simple goitre, the basal metabolic rate being normal and the protein-bound serum iodine slightly increased $(8 \cdot 4 \mu \mathrm{g}$. per cent.). The patient was obese and complained of dysmenorrhoea.

With pilocarpine, Serpasil, or hormone therapy the tension was controlled.

\section{Comment}

The six cases described above are summarized in the Table (overleaf).

(1) In all these patients the ocular tension was controlled during a month's treatment with pilocarpine, a month's treatment with Serpasil, and a fortnight of hormone therapy. 
TABLE

SUMMARY OF FINDINGS IN SIX CASES

\begin{tabular}{|c|c|c|c|c|c|c|c|}
\hline \multicolumn{2}{|l|}{ Case No. } & 1 & 2 & 3 & 4 & 5 & 6 \\
\hline \multicolumn{2}{|l|}{ Age (yrs) } & 36 & 19 & 13 & 35 & 27 & 41 \\
\hline \multicolumn{2}{|c|}{ Civil Status } & Married & Single & Single & Single & Single & Married \\
\hline \multicolumn{2}{|c|}{ Complaint } & $\begin{array}{l}\text { Blurred vision } \\
\text { Headaches }\end{array}$ & $\begin{array}{l}\text { Headaches } \\
\text { Heavy eyes }\end{array}$ & Hyperopia & $\begin{array}{l}\text { Heavy eyes } \\
\text { Impaired } \\
\text { vision }\end{array}$ & $\begin{array}{l}\text { Headache } \\
\text { Blurred vision } \\
\text { Palpitations } \\
\text { Sweating }\end{array}$ & $\begin{array}{l}\text { Orbital pain } \\
\text { Blurred vision }\end{array}$ \\
\hline \multirow{2}{*}{$\begin{array}{l}\text { Ocular } \\
\text { Tension } \\
\text { (mm.Hg } \\
\text { Schiötz) }\end{array}$} & Right & 30 & 28 & 27 & 35 & 30 & 26 \\
\hline & Left & 30 & 28 & 27 & 25 & 30 & 26 \\
\hline \multicolumn{2}{|c|}{$\begin{array}{l}\text { Dark-adaptation } \\
\text { Curve }\end{array}$} & Rise & Rise & Rise & Doubtful & Large rise & Rise \\
\hline \multicolumn{2}{|c|}{ Provocative Tests } & Negative & $\begin{array}{l}\text { Water-drink- } \\
\text { ing rise of } \\
14 \mathrm{~mm} . \mathrm{Hg}\end{array}$ & $\begin{array}{l}\text { Water-drink- } \\
\text { ing rise of } \\
24 \mathrm{~mm} . \mathrm{Hg}\end{array}$ & Negative & $\begin{array}{c}\text { Homatropic } \\
\text { rise to over } \\
40 \mathrm{~mm} . \mathrm{Hg}\end{array}$ & Negative \\
\hline \multicolumn{2}{|c|}{$\begin{array}{l}\text { Basal Metabolic } \\
\text { Rate }\end{array}$} & Normal & Normal & Normal & Raised & High & Normal \\
\hline \multicolumn{2}{|c|}{$\begin{array}{l}\text { Protein-bound } \\
\text { Serum Iodine }\end{array}$} & $7 \cdot 9$ & Normal & Normal & $8 \cdot 9$ & $9 \cdot 0$ & $8 \cdot 4$ \\
\hline \multicolumn{2}{|c|}{ Thyroid Gland } & $\begin{array}{l}\text { Hypertrophy } \\
\text { of medial } \\
\text { lobe }\end{array}$ & Hypertrophic & $\begin{array}{l}\text { Slightly hyper- } \\
\text { trophic }\end{array}$ & Simple goitre & $\begin{array}{l}\text { Simple goitre } \\
\text { (nodular) }\end{array}$ & Simple goitre \\
\hline \multicolumn{2}{|c|}{$\begin{array}{l}\text { Dermato- } \\
\text { graphism }\end{array}$} & Positive & 一 & 一 & Positive & - & - \\
\hline \multicolumn{2}{|c|}{$\begin{array}{l}\text { Other Patho- } \\
\text { logical Findings }\end{array}$} & $\begin{array}{l}\text { Obesity } \\
\text { Dysmenor- } \\
\text { rhoea } \\
\text { Neuro- } \\
\text { regulatory } \\
\text { asthenia }\end{array}$ & $\begin{array}{l}\text { Obesity } \\
\text { Hypo- } \\
\text { menorrhoea }\end{array}$ & 一 & $\begin{array}{l}\text { Dysmenor- } \\
\text { rhoea }\end{array}$ & $\begin{array}{l}\text { Dysmenor- } \\
\text { rhoea } \\
\text { Hyper- } \\
\text { emotion } \\
\text { Hand tremor } \\
\text { Palpitations }\end{array}$ & $\begin{array}{l}\text { Obesity } \\
\text { Dysmenor- } \\
\text { rhoea }\end{array}$ \\
\hline \multicolumn{2}{|c|}{$\begin{array}{l}\text { Results of Treat- } \\
\text { ment with } \\
\text { Pilocarpine, } \\
\text { Serpasil, and } \\
\text { Hormones }\end{array}$} & Effective & $\begin{array}{c}\text { Variable } \\
\text { Tension } \\
(18-40 \\
\text { mm. Hg) } \\
\text { Slight } \\
\text { improvement } \\
\text { on Serpasil }\end{array}$ & $\begin{array}{l}\text { More com- } \\
\text { fortable on } \\
\text { Serpasil and } \\
\text { hormones }\end{array}$ & Effective & $\begin{array}{l}\text { Serpasil } \\
\text { slightly } \\
\text { effective } \\
\text { Propycil } \\
\text { effective }\end{array}$ & Effective \\
\hline
\end{tabular}

(2) The fall in tension was not parallel to the miosis caused by the pilocarpine. Although the pupils were pinhole, the tension remained high.

(3) All the patients benefited more or less from Serpasil.

(4) Simple goitre was associated with hyperthyroidism in Case 5 and this patient benefited from iodine preparations. Even this one case is enough to suggest a relationship between ocular hypertension and thyroid dysfunction.

(5) In three cases protein-bound serum iodine was higher than normal and in Case 1 it reached the upper limit of normal.

(6) All the female patients had hypo- or dys-menorrhoeic disturbances.

(7) In spite of repeated perimetric, campimetric, and gonioscopic investigations, none of the changes usually associated with glaucoma was observed, and these cases must be regarded as different from those of classical glaucoma. 
(8) A rise in the threshold of dark-adaptation curves was evident in all cases.

(9) Provocative tests, preferably done in periods of normal tension, were positive in three cases, doubtful in one, and negative in two.

\section{Conclusion}

Nothing has been found in the available literature on the relationship between simple goitre and chronic glaucoma. Only Sugar (1957) mentions glaucoma in malignant exophthalmos which has nothing to do with the cases reported here.

Figueira (1952) reported five cases in which he found no relationship between glaucoma and the thyroid gland.

We call the hypertension in these cases "ocular hypertension" instead of glaucoma, as they show a clinical picture quite different from that of glaucoma.

If, in the presence of simple goitre, good results from either Serpasil (Kaplan and Pilger, 1957) or iodine preparations are not a mere coincidence, these cases suggest that the cause lies in some disturbance in the diencephalon, in which the centre of endocrine function lies, and may be considered important in drawing attention to this possibility.

\section{REFERENCES}

FIGUeIRA, A. (1952). Rev. bras. Oftal., 10, 287 (Ophthal. Lit. (Lond.), 6, 4426).

KAPLAN, M. R., and PILGER, I. S. (1957). Amer. J. Ophthal., 43, 550.

MAGIroT, A. (1950). Ann. Oculist. (Paris), 183, 817.

RADOVICI (1955). Ibid., 188, 881.

REDSLOB, E. (1955). Ibid., 188, 781.

SugAR, H. S. (1957). "The Glaucomas", 2nd ed., p. 358 Hoeber, New York. 